\title{
De arbeidsongeschiktheidsverzekering
}

\author{
Allerminst een rustig bezit: drie actuele discussies uitgediept
}

\author{
$M r . E . W . B o s c b^{*}$
}

\section{Inleiding}

Het Centraal Bureau voor de Statistiek rapporteert de afgelopen jaren steevast een groei van het aantal zelfstandigen zonder personeel (zzp'ers). Inmiddels zouden dit er meer dan een miljoen zijn. Op 23 juli 2018 oordeelde de Rechtbank Amsterdam ${ }^{1}$ dat de overeenkomst die een bezorger sloot met het bedrijf Deliveroo niet kwalificeert als arbeidsovereenkomst. Dus was de bezorger niet in loondienst, maar een zelfstandig ondernemer. Deze maatschappelijke trend is (zeker op korte termijn) niet te keren.

Een van de aspecten van het ondernemerschap is dat zelfstandigen niet collectief via de overheid verzekerd zijn voor de werknemersverzekeringen, zoals voor (blijvende) arbeidsongeschiktheid. Om dit risico - je zult maar blijvend arbeidsongeschikt worden en daardoor niet meer in je levensonderhoud kunnen voorzien - af te dekken kan een ondernemer bij een private verzekeraar een arbeidsongeschiktheidsverzekering afsluiten.

Met het toenemen van het aantal zelfstandig ondernemers neemt ook het maatschappelijk belang van de arbeidsongeschiktheidsverzekering toe. Immers, sluit een zelfstandig ondernemer geen arbeidsongeschiktheidsverzekering en raakt hij wel arbeidsongeschikt, dan rest - uiteindelijk, nadat het eventuele vermogen en de overwaarde in de eigen woning zijn 'opgegeten' - vaak slechts een beroep op de bijstand. Daarmee is de arbeidsongeschiktheidsverzekering voor een groeiende groep werkenden de enige manier om bij arbeidsongeschiktheid een inkomensvervangende uitkering te verkrijgen.

Vanuit de letselschadewereld klinken geregeld geluiden ${ }^{2}$ dat de opstelling van verzekeraars verhardt en dat schades minder makkelijk worden geregeld. Aan de hand van enige recente jurisprudentie zal in dit artikel worden stilgestaan bij drie pijnpunten in de behandeling van claims op de arbeidsongeschiktheidsverzekering. Hoe gaan arbeidsongeschiktheidsverzekeraars hiermee om? Wat leert de recente(re) jurisprudentie ons?

Mr. E.W. Bosch is advocaat bij Vogelaar Bosch Spijer Advocaten te Honselersdijk.

1. ECLI:NL:RBAMS:2018:5183.

2. Vgl. https://www.asp-advocaten.nl/opstelling-verzekeraars-letselschadeverhardt.
In dit artikel zal ik eerst de aard en kenmerken van de private arbeidsongeschiktheidsverzekering behandelen (par. 2). Vervolgens zal ik op hoofdlijnen bespreken hoe de claimbehandeling eruitziet bij een beroep op een dergelijke verzekering (par. 3). Tegen die achtergrond ga ik vervolgens in op drie discussies die recent in de jurisprudentie aan bod kwamen.

De eerste discussie die ik bespreek (par. 4), ziet op de vraag: 'Wie wijst de deskundige aan die de mate van arbeidsongeschiktheid bepaalt?' Is dat de verzekeraar of zijn dat partijen gezamenlijk. De tweede discussie ziet op de schatting van het percentage arbeidsongeschiktheid (par. 5). Kun je bijvoorbeeld tegen een zzp'er zeggen dat hij weliswaar inderdaad volledig arbeidsongeschikt is voor zijn uitvoerende werk, maar nog wel de administratie kan doen, zodat hij voor dat deel niet arbeidsongeschikt is? De derde en tevens laatste discussie gaat over de vraag welke maatstaf er moet worden aangelegd indien een kandidaat-verzekeringnemer bij het aangaan van de verzekering zijn mededelingsplicht heeft geschonden, voor de bepaling van de gevolgen daarvan (par. 6). Is het de vraag wat de verzekeraar, op grond van zijn eigen acceptatiebeleid had gedaan wanneer hij de ware stand van zaken kende, of wordt daarvan geabstraheerd en wordt getoetst aan hetgeen een redelijk handelend verzekeraar zou hebben gedaan?

\section{De arbeidsongeschiktheidsverzekering}

Wanneer ik het in dit artikel heb over de arbeidsongeschiktheidsverzekering, dan bedoel ik daarmee een arbeidsongeschiktheidsverzekering die wordt gesloten bij een particuliere verzekeraar, die tegen ontvangst van een premie het financiële risico van arbeidsongeschiktheid afdekt.

Inmiddels zijn er ook verwante polissen op de markt gebracht die enige overlap hebben met de arbeidsongeschiktheidsverzekering, maar bijvoorbeeld alleen dienen om de kosten van de hypotheek te kunnen opvangen bij arbeidsongeschiktheid. Op dergelijke aanverwante verzekeringen ziet dit artikel niet, hoewel de aangeroerde discussies mutatis mutandis ook voor dat soort verzekeringen relevant kunnen zijn.

Bij het afsluiten van een particuliere arbeidsongeschiktheidsverzekering heeft de kandidaat-verzekeringnemer/ondernemer de nodige keuzes te maken. Verzekert hij zich voor het maximale bedrag (de meeste verzekeraars bieden een dekking aan van maximaal $80 \%$ van het inkomen zonder arbeidsonge- 
schiktheid), of neemt hij genoegen met een lagere uitkering als hij arbeidsongeschikt raakt (waaraan dan ook een lagere premie is gekoppeld)?

Ook is er keuze in de vorm van arbeidsongeschiktheid. Kiest de ondernemer voor dekking tegen beroepsarbeidsongeschiktheid, dan keert de verzekeraar uit als de verzekerde het eigen beroep niet meer kan uitoefenen. Verzekert hij zich op een 'gangbare arbeid'-polis, dan wordt niet alleen gekeken of het eigen beroep van de verzekerde nog passend is, maar ook of de verzekerde nog ander - gangbaar - werk kan doen. De premies van dergelijke verzekeringen zijn doorgaans lager, maar er is ook minder snel sprake van arbeidsongeschiktheid.

Veelal zijn arbeidsongeschiktheidsverzekeringen sommenverzekeringen. Dat wil zeggen dat niet concreet wordt gekeken naar de geleden schade, maar dat het percentage arbeidsongeschiktheid (dat doorgaans ten minste $25 \%$ moet zijn, wil de polis tot uitkering komen) wordt vastgesteld. Na de (zelf te kiezen) eigenrisicotermijn worden een eerste jaarrente en een na-eerste jaarrente afgesproken. Het eerste wordt doorgaans aangeduid als het A-bedrag, het tweede als het B-bedrag. Is bekend hoeveel procent de verzekerde arbeidsongeschikt is, dan wordt ofwel dit percentage maal de verzekerde rente uitgekeerd, ofwel in een tabel gekeken hoeveel procent uitkering gekoppeld is aan dit percentage arbeidsongeschiktheid, waarna het gevonden percentage wordt toegepast op de verzekerde jaarrente.

Is er sprake van een schadeverzekering, dan is in plaats van het percentage arbeidsongeschiktheid maal de jaarrente, de daadwerkelijk door de verzekerde geleden schade door de arbeidsongeschiktheid (lees: het daadwerkelijke inkomensverlies) verzekerd.

\section{De behandeling van de claim}

$\mathrm{Na}$ de arbeidsongeschiktheidsmelding wordt de claim door de verzekeraar in behandeling genomen. Doorgaans wordt eerst medische informatie ingewonnen in de behandelend sector. Deze wordt beoordeeld door een medisch adviseur. Veelal is dit een arts die in dienst is van de verzekeraar. Vervolgens wordt - zodra een medische eindsituatie is ingetreden - een expertise uitgevoerd door een onafhankelijk arts. Deze stelt vast welke aandoening of welk trauma de verzekerde opliep. Daarna worden deze medische gegevens omgezet in een functionele-mogelijkhedenlijst (FML) of een beperkingenprofiel. Hierin staan de beperkingen van de verzekerde gekwantificeerd. Met dit profiel wordt vervolgens door een arbeidsdeskundige nagegaan voor welk deel (in procenten) de ondernemer (beroeps)arbeidsongeschikt is. Is dat meer dan $25 \%$ en is de eigenrisicotermijn voorbij, dan keert de verzekeraar het daarmee corresponderende percentage vermenigvuldigd met de jaarrente uit.

Deze uitkering loopt totdat de verzekerde ofwel weer arbeidsgeschikt is, ofwel tot de einddatum van de verzekering. Net welke van de twee eerder is bereikt.
Zoals uit het voorgaande blijkt, zijn er nogal wat deskundigen bij betrokken om tot een correcte schatting van het percentage arbeidsongeschiktheid te komen. Daarbij komt ook nog het financieel velang van partijen: ; zelfs bij een relatief lage jaarrente kan door de looptijd het financieel belang (zeer) groot zijn. Het spreekt daarom voor zich dat de vaststelling van het percentage arbeidsongeschiktheid voor beide partijen - zij het tegengesteld - van groot (financieel) belang is. Wie echter in de wet op zoek gaat naar bepalingen over de particuliere arbeidsongeschiktheidsverzekering komt bedrogen uit. Veel verder dan enkele generieke bepalingen over 'de schadeverzekering'3 of 'de sommenverzekering' ${ }^{4}$ komt het Burgerlijk Wetboek (BW) niet. De verzekering ter zake van arbeidsongeschiktheid wordt, zoals zoveel verzekeringen, dan ook vooral beheerst door de polisvoorwaarden van de verzekering.

\section{Wie wijst de deskundige aan?}

Bij die polisvoorwaarden lopen we direct tegen de eerste hobbel op. Want wie bepaalt het percentage (beroeps)arbeidsongeschiktheid? Zoals hiervoor aan de orde kwam, is daar de nodige deskundige voorlichting bij nodig. Maar wie kiest de persoon van de deskundige? Die vraag is niet geheel zonder betekenis. Wanneer de verzekerde lijdende is aan een duidelijke en objectiveerbare aandoening, waarover veel bekend is, dan zal het weinig verschil maken welke deskundige wordt benoemd. Gaat het echter om een minder concrete of minder objectiveerbare aandoening, dan kan het groot verschil maken welke deskundige wordt benaderd. ${ }^{5}$ Immers, afhankelijk van de vraag tot welke 'school' de deskundige behoort (voor- of tegenstander van een bepaalde discussie), is dan met het aanwijzen van de deskundige de uitkomst gegeven. Wie de deskundige aanwijst, blijkt uit de toepasselijke polisvoorwaarden. Deze vraag heeft echter inmiddels ook een Europees aspect.

\subsection{Depolisbepaling...}

Doorgaans bevatten polisvoorwaarden bepalingen als:

'Wij stellen de mate van arbeidsongeschikt vast aan de hand van rapportages van door ons aan te wijzen deskundigen.

(...)

Wij drukken de mate van arbeidsongeschiktheid uit in een percentage. Dit percentage noemen wij het arbeidsongeschiktheidspercentage.'

Of:

'Zolang verzekerde arbeidsongeschikt is, zullen de mate van arbeidsongeschiktheid, de omvang van de uitkering en de periode waarover deze zal gelden, worden vastgesteld

3. Art. 7:944 t/m 7:963 BW.

4. Art. 7:964 t/m 7:974 BW.

5. Vgl. in het kader van de behandeling van letselschades het pleidooi van Smeehuijzen, in: J.L. Smeehuijzen, Wie is de deskundige? Pleidooi voor een 'disclosure statement', TVP 2003, p. 126-129.

6. Ontleend aan Rb. Gelderland 25 november 2015, ECLI:NL:RBGEL: 2015:7395. 


\section{Maandblad \\ Vermogensrecht}

door de maatschappij aan de hand van gegevens van door de maatschappij aan te wijzen medische en andere deskundigen. Van deze vaststelling zal telkens zo spoedig mogelijk na ontvangst daarvan aan verzekeringnemer mededeling worden gedaan. Indien verzekeringnemer niet binnen 30 dagen zijn bezwaar heeft kenbaar gemaakt, wordt hij geacht het standpunt van de maatschappij te aanvaarden. ${ }^{7}$

In beide geciteerde polisbepalingen is het de verzekeraar die de deskundige aanwijst. Dat komt vreemd over, als wordt vergeleken met de afwikkeling van buitencontractuele letselschades, waarbij verzekeraar en gelaedeerde vooraf overleggen over de persoon van en de vraagstelling aan de deskundige. De vraag is of dergelijke polisbepalingen (nog) zijn toegestaan op grond van het Europees recht.

\section{2 ... en de 'blauwe lijst'}

Sinds 2015 is er namelijk enige discussie over deze bepalingen. Daarbij is een hoofdrol weggelegd voor Richtlijn 93/13/EEG betreffende oneerlijke bedingen in consumentenovereenkomsten (hierna ook: Richtlijn). Dit is de zogenoemde 'blauwe lijst'.

Het arrest van het Europees Hof van Justitie van 23 april $2015,{ }^{8}$ waarin het Hof oordeelde over de vraag of de definitie van 'volledige arbeidsongeschiktheid' een kernbeding is in de zin van Richtlijn 93/13/EEG, ${ }^{9}$ maakte dat de Nederlandse rechter zich realiseerde dat het Europees recht invloed heeft op de beoordeling van geschillen over de arbeidsongeschiktheidsverzekering. Anders dan bij de bekende(re) grijze ${ }^{10}$ en zwarte $^{11}$ lijst uit het BW is de rechter gehouden om de 'blauwe lijst' ambtshalve toe te passen. ${ }^{12}$

Het Gerechtshof Arnhem-Leeuwarden overwoog vervolgens, ambtshalve als voorlopig oordeel, bij arrest van 6 maart $2016^{13}$ dat de in het geding zijnde polisvoorwaarden van de verzekering vielen binnen het toepassingsgebied van de Richtlijn. $\mathrm{Na}$ een reactie van partijen op dit voorshandse oordeel concludeerde het hof ${ }^{14}$ dat moest worden nagegaan of er een 'aanzienlijke en ongerechtvaardigde verstoring bestond in het evenwicht tussen partijen'.

Het hof overwoog dat uit het vaststellen van de mate van arbeidsongeschiktheid aan de hand van door de verzekeraar aan te wijzen deskundigen reeds volgde dat de verzekeraar een-

7. Ontleend aan conclusie A-G Hartlief d.d. 6 juli 2018, ECLI:NL:PHR: 2018:788.

8. HvJ EU 23 april 2015, RAV 2015/70.

9. Richtlijn 93/13/EEG betreffende oneerlijke bedingen in consumentenovereenkomsten. Analoog aan de bekende grijze lijst (art. 6:237 BW) en zwarte lijst (art. 6:236 BW), ook wel de 'blauwe lijst' genoemd.

10. Art. 6:237 BW.

11. Art. $6: 236 \mathrm{BW}$.

12. HR 13 september 2013, ECLI:NL:HR:2013:691, NJ 2014/274 m.nt. H.B. Krans.

13. Hof Arnhem-Leeuwarden 6 maart 2016, ECLI:NL:GHARL:2016:2316.

14. Hof Arnhem-Leeuwarden 30 augustus 2016, ECLI:NL:GHARL: 2016:6941. zijdig het recht had om de mate van arbeidsongeschiktheid te bepalen, en daarmee of, en zo ja in welke mate, hij zelf tot enige uitkering was gehouden. Het hof onderkende dat de verzekerde daarop geen in de polis geregelde invloed kon uitoefenen. Dat werd, zo oordeelde het hof, verder versterkt doordat de rechter ex art. 7:904 lid $1 \mathrm{BW}$ alleen een marginale toets zou kunnen aanleggen.

Het hof oordeelt uiteindelijk dat de bepaling in de polisvoorwaarden als een oneerlijk beding in de zin van de richtlijn heeft te gelden, waardoor het hof verplicht was deze bepaling verder buiten toepassing te laten. ${ }^{15}$

\subsection{Intermezzo: de consument ...}

Dat de Rechtbank Gelderland op 27 juli $2016,{ }^{16}$ bij een soortgelijke bepaling in een verzuimverzekering, tot het oordeel kwam dat de bepaling niet onredelijk bezwarend is, lijkt vreemd, maar is dat niet. Niet alleen omdat de rechtbank overwoog dat de stellingen op dit punt niet voldoende waren uitgewerkt, maar ook omdat de eisende partij in die procedure geen consument was.

Voor een succesvol beroep op Richtlijn 93/13/EEG is het immers noodzakelijk dat het gaat om een overeenkomst tussen een professionele partij enerzijds (de verzekeraar) en een consument anderzijds. Een consument is volgens art. 2 onder b Richtlijn iedere 'natuurlijke persoon' die bij onder de Richtlijn vallende overeenkomsten handelt voor doeleinden die buiten zijn bedrijfs- of beroepsactiviteiten vallen. ${ }^{17}$ Een rechtspersoon, zoals een besloten vennootschap, is dus niet als consument te beschouwen. Dit blijkt niet alleen uit de omschrijving die in de Richtlijn is opgenomen, maar is ook door het Hof van Justitie in het Cape/Idealservice-arrest ${ }^{18}$ uitdrukkelijk bevestigd.

Dit is van belang omdat het in de praktijk niet altijd de ondernemer in privé is die de verzekeringnemer is op de polis. Soms is dat een holding of zelfs een werkmaatschappij, temeer wanneer men niet het inkomen van de ondernemer wilde verzekeren, maar bijvoorbeeld de meerkosten van een tijdelijk vervanger. Het is van belang om te realiseren dat alleen wanneer de ondernemer in privé de verzekeringnemer ${ }^{19}$ is, een beroep op Richtlijn 93/13/EEG mogelijk is.

\section{4 ... de lagere jurisprudentie ...}

In navolging van het arrest van het Gerechtshof ArnhemLeeuwarden volgden meer rechters dit spoor. De Rechtbank

15. Vgl. HvJ EU 30 mei 2013, C-488/11, ECLI:EU:C:2013:341.

16. Rb. Gelderland 27 juli 2016, ECLI:NL:RBGEL:2017:4772.

17. HvJ EU 30 mei 2013, C-0488/11, ECLI:EU:C:2013:341 (Asbeek Brusse).

18. HvJ EG 22 november 2001, gevoegde zaken C-541/99 en C-542/99, ECLI:EU:C:2001:625 (Cape/Idealservice).

19. Het is goed om te realiseren dat 'verzekeringnemer' en 'verzekerde' twee verschillende begrippen zijn. Met de eerste wordt de contractant aangeduid die de verzekering afsloot. Met de tweede wordt degene aangeduid die wegens arbeidsongeschiktheid is verzekerd. Beide personen kunnen samenvallen wanneer de ondernemer zowel contractant als verzekerde is. Maar dat hoeft niet per se. 
Rotterdam sloot zich op 23 november $2016^{20}$ (woordelijk) aan bij de argumentatie van het Gerechtshof Arnhem-Leeuwarden. Weliswaar noemden de toepasselijke polisvoorwaarden in de Rotterdamse zaak de mogelijkheid van bezwaar, maar dat zag er slechts op dat de verzekeringnemer dertig dagen de tijd had om bezwaar aan te tekenen tegen een ingenomen standpunt. Deed hij dit niet (tijdig), dan werd hij geacht het standpunt van de verzekeraar te hebben aanvaard. Daarnaast vond de rechter in Rotterdam nog van belang dat uit de polisbepaling bleek dat de verzekeraar zich niet gebonden achtte aan de door hem te ontvangen rapportages van de deskundigen. Dit waren slechts adviezen. Adviezen op basis waarvan de verzekeraar zelf het percentage arbeidsongeschiktheid zou bepalen. Tegen die achtergrond kwam de rechtbank tot het oordeel dat de polisvoorwaarden een ongerechtvaardigde verstoring van het evenwicht in de zin van art. 3 lid 1 Richtlijn waren.

Ook het Gerechtshof Amsterdam zag in zijn arrest van 12 juli 2016, ${ }^{21}$ na bestudering van het procesdossier, ambtshalve onder ogen dat appellant wellicht als een consument in de zin van de Richtlijn moest worden beschouwd. Mocht dat het geval zijn, zo overwoog het hof, dan doet zich de vraag voor of er sprake is van een oneerlijk beding. Tegen die achtergrond werd een comparitie gelast. ${ }^{22}$

Ook de Rechtbank Gelderland stelde in haar vonnis van 27 september $2017^{23}$ ambtshalve de toepassing van de Richtlijn aan de orde. Ter zake worden partijen in de gelegenheid gesteld om een akte te nemen. Uit het tussenvonnis van 31 januari 2018 blijkt dat eiser dit wel deed, maar Achmea niet. Eiser heeft zich op het standpunt gesteld een consument te zijn, dat de Richtlijn aldus van toepassing is en dat de bepaling een onredelijk beding was. $\mathrm{Nu}$ Achmea dit niet, althans onvoldoende, had weersproken, kon de rechtbank niet anders ${ }^{24}$ dan aannemen dat het een oneerlijk beding was in de zin van art. 3 lid 1 Richtlijn, zodat deze polisbepaling buiten beschouwing bleef. De rechtbank benoemde vervolgens een verzekeringsgeneeskundige. Zodra de verzekeringsgeneeskundige heeft gerapporteerd, mogen partijen op diens rapportage reageren, waarna een arbeidsdeskundige de mate van arbeidsongeschiktheid zal moeten bepalen. Daarmee doet de rechtbank de vaststelling van de arbeidsongeschiktheid dunnetjes over.

\section{5 ... de prejudiciële vragen}

Wanneer ook de Rechtbank Den Haag zich in een procedure tegen Nationale-Nederlanden gesteld ziet voor de vraag of Richtlijn 93/13/EEG van toepassing is, stelt zij daarover prejudiciële vragen aan de Hoge Raad. In een tussenvonnis van

\footnotetext{
20. Rb. Rotterdam 23 november 2016, ECLI:NL:RBROT:2016:9380, JA 2017/60 m.nt. E.J. Wervelman.

21. Hof Amsterdam 12 juli 2016, ECLI:NL:GHAMS:2016:2856.

22. Wat de uitkomst van deze procedure is, is niet terug te vinden op rechtspraak.nl.

23. Rb. Gelderland 27 september 2017, ECLI:NL:RBGEL:2017:4961.

24. Vgl. art. 149 lid 1 Rv.
}

15 november $2017^{25}$ heeft de rechtbank aan partijen kenbaar gemaakt dat zij voornemens was om prejudiciële vragen ${ }^{26}$ te stellen aan de Hoge Raad. Hierop hebben partijen bij akte mogen reageren. In haar tussenvonnis van 7 maart $2018^{27}$ formuleert de rechtbank metterdaad vijf vragen, die deels uiteenvallen in enkele subvragen. Het gaat onder meer om de vraag welke gezichtspunten in aanmerking moeten worden genomen 'bij het vaststellen of een arbeidsongeschiktheidsverzekering is aangegaan door een verzekerde [bedoeld zal zijn: verzekeringnemer; EB] als consument'. Of de specifieke bepaling een oneerlijk beding is, zowel ten aanzien van het aanwijzen van de deskundigen alsook ten aanzien van de duur van de bezwaartermijn, en of het daarbij nog van belang is of een verzekeringnemer op grond van de polisvoorwaarden recht heeft op een herbeoordeling. En: als de specifieke bepaling een oneerlijk beding is, wat is dan de status van de reeds bestaande rapporten? Mogen deze worden voorgelegd aan de nieuw te benoemen deskundigen?

Op 6 juli 2018 heeft A-G Hartlief geconcludeerd ${ }^{28}$ in deze zaak. In zijn zeer uitvoerige (geprint 63 pagina's) en lezenswaardige conclusie schetst Hartlief de feiten, het procesverloop, de maatschappelijke achtergrond en de verzekeringspraktijk. Vervolgens gaat hij nader in op de Richtlijn, waarna hij afsluitend de prejudiciële vragen beantwoordt. Bij de vraag of de verzekeringnemer handelde als consument, acht Hartlief - terecht - doorslaggevend of de verzekeringnemer een 'natuurlijk persoon' is en of de verzekering strekt tot aanvulling van het privé-inkomen of tot voldoening van zakelijke lasten.

Alvorens Hartlief toekomt aan de vraag of de betreffende bepaling in de polisvoorwaarden een oneerlijk beding is, moet eerst de hobbel worden genomen of er sprake is van een kernbeding zoals - door Nationale-Nederlanden - betoogd werd. Is dat het geval, dan komt men aan toetsing van de polisbepaling niet toe. Op overtuigende gronden concludeert Hartlief dat de betreffende bepaling - zowel voor de verzekeringnemer als voor de verzekeraar - van belang is en mogelijk ook invloed heeft op de hoogte van de premie, maar dat dit niet makt dat het een 'kernbeding' is. Met die conclusie komt de inhoudelijke beoordeling in beeld.

In het vervolg van zijn conclusie bespreekt Hartlief de argumenten voor en tegen de betreffende bepaling. Dat begint met de constatering dat diverse partijen, waaronder de Ombudsman, ${ }^{29}$ het Kifid, maar ook Wervelman ${ }^{30}$ (zij het in beperkte(re) mate), een beroep hebben gedaan op verzekeraars om

25. N.g., te kennen uit: Rb. Den Haag7 maart 2018, ECLI:NL:RBDHA: 2018:273.

26. In de zin van art. $392 \mathrm{Rv}$.

27. Rb. Den Haag 7 maart 2018, ECLI:NL:RBDHA:2018:2733.

28. Gepubliceerd op rechtspraak.nl op 26 juli 2018: ECLI:NL:PHR: 2018:788.

29. In diens jaarverslagen 2005 en 2007

30. E.J. Wervelman, De particuliere arbeidsongeschiktheidsverzekering, Deventer: Wolters Kluwer 2016, p. 356. 
afstemming te zoeken met de verzekeringnemer over de te benoemen deskundigen. Voorts overweegt Hartlief dat de afwezigheid van een inspraakmogelijkheid haaks staat op het in letselschadezaken algemeen aanvaarde uitgangspunt dat partijen in ieder geval moeten proberen de schadeafwikkeling in onderling overleg te regelen. Daarbij merkt hij mijns inziens terecht op dat dit verschil zich niet kan laten verklaren door het argument dat partijen over deze gang van zaken overeenstemming hebben bereikt: de kern van de zaak is immers juist of die afspraak door de beugel kan. ${ }^{31}$

Door de verzekeraar is nog gewezen op de uitvoeringspraktijk voor de werknemersverzekeringen. Daar is het het UWV dat bepaalt welke deskundigen worden ingeschakeld, hoewel het daar vaak eigen UWV-personeel zal zijn dat de beoordelingen maakt. Hartlief wijst er echter op dat ook in het bestuursrecht is erkend dat een uitkeringsgerechtigde hierdoor op achterstand kan komen te staan. Hiervoor bestaan compensatiemechanismen, zoals de actieve rol van de (bestuurs)rechter, die passen binnen een bestuursrechtelijke context.

Terecht heeft Hartlief er (ook) oog voor dat de cumulatie in de bepaling (enerzijds dat de verzekeraar eenzijdig de persoon van en de vraagstelling aan de deskundigen mag bepalen en anderzijds dat de verzekeringsnemer binnen een bepaalde termijn moet klagen, omdat hij anders geacht wordt het standpunt van de verzekeraar te hebben geaccepteerd) van invloed is op de vraag of de betreffende bepaling een oneerlijk beding is.

Opvallend aan de voorliggende casus is dat Nationale-Nederlanden zich op het standpunt stelt dat de betreffende bepaling in haar polisvoorwaarden slechts leidt tot een standpuntbepaling en geen vaststellings- of bewijsovereenkomst ${ }^{32}$ is. Hartlief wijst er terecht op dat in eerdere procedures over gelijksoortige bedingen daarvan wel is uitgegaan. ${ }^{33}$ Over de vraag of art. 14 van de polisvoorwaarden een vaststellingsbeding is, schrijft Hartlief:

'Of artikel $14 \mathrm{PV}$ een vaststellingsbeding is, is een kwestie van uitleg. Daarbij geldt hetgeen hiervoor (...) is opgemerkt over uitleg van polisvoorwaarden in het licht van de Richtlijn. De tekst van het beding is niet zonder meer duidelijk: daarin staat dat "de mate van arbeidsongeschiktheid, de omvang van de uitkering en de periode waarvoor deze zal gelden, worden vastgesteld door de maatschappij" (...) en dat de verzekeringnemer wordt "geacht het standpunt van de maatschappij te aanvaarden" indien hij de bezwaartermijn ongebruikt laat verstrijken. In ieder geval ontbreekt een term als "beslissing”. Dat zou een sterke aanwijzing vormen voor een vaststellingsbeding in de zin van art. 7:900 lid 2 BW. Belangrijker lijkt mij nog dat Nationale-Nederlanden zelf heeft benadrukt dat een gang naar

31. A-G Hartlief in ECLI:NL:PHR:2018:788, randnr. 7.39.

32. In de zin van art. 7:900 BW.

33. A-G Hartlief in ECLI:NL:PHR:2018:788, randnr. 7.14. de rechter (of de Geschillencommissie van het Kifid) "gewoon" open blijft staan: dit wordt de verzekeringnemer onder meer door middel van brochures duidelijk gemaakt. Dat sluit ook aan bij de Protocollen, die voorschrijven dat de verzekeraar de verzekerde uitdrukkelijk de mogelijkheid moet bieden de zaak voor te leggen aan de rechter. Deze ruimte voor gewone rechterlijke beoordeling past niet bij een regime van een vaststellingsbeding in de zin van art. 7:900 lid 2 BW. Overigens zou ook een eventuele uitleg contra proferentem, die de Richtlijn voorschrijft bij onduidelijke bedingen, meebrengen dat het hier niet om een vaststellingsbeding gaat: dat is immers de voor de consument meest gunstige uitleg.

Wat mij betreft is de meest aannemelijke uitleg daarom dat de uit artikel 14 PV voortvloeiende "vaststelling" door de verzekeraar niet het karakter heeft van een beslissing voortvloeiend uit een vaststellingsbeding in de zin van art. 7:900 lid 2 BW.'

Hartlief concludeert in antwoord op vraag 2 vervolgens dat alhoewel serieuze vraagtekens zijn te plaatsen bij de eenzijdige wijze van vaststelling van het percentage arbeidsongeschiktheid, hij er niet van overtuigd is dat de bepaling een oneerlijk beding in de zin van de Richtlijn is. Hij kan zich zeer wel voorstellen, en zou het ook wenselijk vinden, zo schrijft hij, dat verbetering wordt gerealiseerd aan het front van de wijze waarop claims door verzekeraars op een arbeidsongeschiktheidsverzekering worden behandeld, maar dat het kader van een rechterlijke oneerlijkheidstoetsing (na een beroep op de Richtlijn) hiervoor niet het geëigende middel is. Ook Hartlief zit wat dat betreft op het spoor van de Ombudsman en Wervelman: het is aan de branche, aan verzekeraars dus, om deze handschoen op te pakken. ${ }^{34}$

Daar waar Hartlief als beginpunt heeft gekozen dat de betreffende bepaling geen vaststellingsbeding is en dat ook na het verstrijken van de gestelde termijn 'de vaststelling' nog altijd 'gewoon' kan worden aangevochten, is die uitkomst te billijken. Los van het feit dat voor de consument bij lezing van de polisvoorwaarden niet altijd duidelijk zal zijn dat er na de vaststelling door de verzekeraar mogelijk toch nog ruimte is voor een ander oordeel, staat daar in ieder geval tegenover dat er ook verzekeraars zijn die de bepaling wel als vaststellingsbeding uitleggen en een beroep doen op de 'vervaltermijn', als niet tijdig geklaagd is. In die gevallen meen ik dat het oordeel de andere kant op zou moeten doorslaan. Temeer omdat er weinig aanleiding is erop te vertrouwen dat verzekeraars inderdaad de handschoen zullen oppakken. Hartlief citeert immers de verzuchting van de Ombudsman Verzekeringen in zijn jaarverslag over 2007, dat er vooralsnog niets is gedaan met zijn oproep om bij de benoeming van deskundigen overleg te plegen met de verzekeringnemer. Blijkens de onderhavige procedure is er op dit punt sinds deze verzuchting weinig veranderd.

34. A-G Hartlief in ECLI:NL:PHR:2018:788, randnr. 7.56. 
De volgende (prejudiciële) vraag die beantwoord moet worden, is of het bij de hiervoor besproken toetsing van belang is of een verzekeringnemer, op grond van de polisvoorwaarden, recht heeft op een herbeoordeling. De achtergrond van deze vraag is ongetwijfeld dat een contractueel recht op herbeoordeling in positieve zin zou kunnen meewegen, zodat een eventueel door art. 14 van de polisvoorwaarden veroorzaakt nadeel daardoor zou kunnen worden opgeheven.

Aangezien Hartlief concludeert dat art. 14 van de polisvoorwaarden de eerlijkheidstoets kan doorstaan, is 'compensatie' van enig nadeel door een herbeoordeling niet nodig. Zijn conclusie is dan ook dat de omstandigheid dat een 'herbeoordeling' in de polisvoorwaarden is opgenomen niet zonder belang is bij de beoordeling van de bepaling, maar dat wat hem betreft daaraan geen doorslaggevende betekenis toekomt. ${ }^{35}$

Met deze conclusie komt Hartlief niet meer toe aan beantwoording van de vierde en vijfde vraag, die als premisse hebben dat art. 14 van de polisvoorwaarden de eerlijkheidstoets niet kan doorstaan. Voor het geval de Hoge Raad tot een ander oordeel komt, gaat hij daar subsidiair toch op in. Voor deze bijdrage is dat deel van de conclusie echter van minder belang. De geïnteresseerde lezer wordt volledigheidshalve verwezen naar hoofdstuk 9 van de conclusie van de A-G.

Nu A-G Hartlief heeft geconcludeerd, is de Hoge Raad aan zet. De Hoge Raad heeft een aantal mogelijkheden: de Raad kan de A-G volgen, contrair beslissen, maar ook - nu het om uitleg van een EU-richtlijn gaat - zelf prejudiciële vragen stellen aan het Europees Hof van Justitie. ${ }^{36}$ Ik zal niet verhelen dat, alhoewel de conclusie van Hartlief imponeert, ik hoop dat de Hoge Raad (uiteindelijk) tot een ander oordeel komt. Alleen zo zal er, mijns inziens, op korte termijn een wijziging komen in de wijze van benoeming van deskundigen bij de vaststelling van de mate van arbeidsongeschiktheid op de arbeidsongeschiktheidsverzekering. ${ }^{37}$

\section{Gedeeltelijk arbeidsongeschikt?}

In het verlengde van de eerste discussie ligt de tweede discussie, die de laatste tijd vaker in de jurisprudentie opduikt, namelijk de vraag voor welk gedeelte de verzekerde arbeidsongeschikt is. Die vraag komt in verschillende varianten voor.

\subsection{De té theoretische benadering}

De eerste variant is die waarbij de arbeidsdeskundige een zuiver theoretische benadering kiest. Exemplarisch voor deze categorie is het vonnis van de Rechtbank Gelderland van

35. A-G Hartlief in ECLI:NL:PHR:2018:788, randnr. 8.9.

36. Vgl. bijv. HR 9 december 2016, ECLI:NL:HR:2016:2834, waarin de Hoge Raad, waaraan prejudiciële vragen zijn gesteld, op zijn beurt weer prejudiciële vragen stelt aan het $\mathrm{HvJ}$ EU.

37. Bij het ter perse gaan van deze bijdrage heeft de Hoge Raad uitspraak gedaan in deze zaak. Deze uitspraak kon niet meer worden verwerkt in deze bijdrage. In HR 28 september 2018, ECLI:NL:HR:2018:1800 volgt de Hoge Raad in grote lijnen de visie van AG Hartlief. De vraag is in hoeverre dit oordeel ook geldt voor andere arbeidsongeschiktheidsverzekeringen, gelet op de uitgangspunten die de Hoge Raad formuleert.
25 november $2015 .{ }^{38}$ In deze zaak meldde een zelfstandige, die in het kader van een eenmanszaak voornamelijk in bouwprojecten deuren plaatst en afhangt, zich arbeidsongeschikt. Hij sloot een beroepsarbeidsongeschiktheidspolis, die tot uitkering komt vanaf $25 \%$ arbeidsongeschiktheid. De door Achmea ingeschakelde arbeidsdeskundige Eshuis heeft geconcludeerd dat verzekerde na elk kwartier werken een halfuur moet recupereren. Achmea schat de verzekerde daarom af op $67 \%$ arbeidsongeschikt. Daar neemt de verzekerde geen genoegen nemen. De rechtbank overweegt in zijn voordeel:

'(...) De rechtbank is met [eiser] van oordeel dat indien hij op de door Eshuis omschreven wijze zijn werkzaamheden zou moeten uitvoeren, er geen opdrachtgevers zijn te vinden die [eiser] zouden willen inschakelen voor het installeren van deuren en het aanbrengen van hang- en sluitwerk. Een redelijke uitleg van de in artikel 1 van de algemene voorwaarden gegeven definitie van beroepsarbeidsongeschiktheid brengt met zich mee dat ook al zou de verzekerde nog wel in staat zijn om enige tot zijn beroep behorende werkzaamheden te verrichten, maar hij door zijn beperkingen geen reële mogelijkheid heeft om daarmee inkomen te verwerven, hij als volledig arbeidsongeschikt in de zin van de met Achmea gesloten verzekeringsovereenkomst moet worden aangemerkt (...).'

Dit lijkt mij volkomen terecht. De verzekeringnemer kan doorgaans immers niet meer dan $80 \%$ van zijn inkomen verzekeren. Wanneer hij vervolgens op zuiver theoretische gronden slechts gedeeltelijk arbeidsongeschikt wordt geacht, terwijl hij op praktische gronden het resterende inkomen niet kan verwerven vanwege zijn arbeidsongeschiktheid, dan komt hij als ondernemer - ondanks een adequate verzekering - toch in financiële problemen. Zou immers het betoog van Achmea worden gevolgd, dan zou aan de ondernemer niet meer dan $67 \% \times 80 \%=53,6 \%$ van het benodigde inkomen worden uitgekeerd.

\subsection{De taakverschuiving van een zzp'er?}

De tweede variant is die waarbij onderscheid wordt gemaakt tussen de verschillende taken van de ondernemer. Bij het afsluiten van de verzekering, zeker wanneer gekozen wordt voor de verzekering van de beroepsarbeidsongeschiktheid, wordt op de polis aangetekend wat het beroep is van de ondernemer. Dat beroep kan zowel uitvoerende als niet-uitvoerende werkzaamheden met zich brengen. Te denken valt aan een zzp'er die stukadoor is. Hij heeft opgegeven dat hij van zijn werkweek $75 \%$ besteedt aan 'stukadoren' en $25 \%$ aan acquisitie, het uitbrengen van offertes en het maken van facturen. Door een ongeval kan hij zijn werk als stukadoor niet meer uitoefenen, maar acquisitie, offertes en facturen maken zijn onverminderd mogelijk. Is deze zzp'er 75\% arbeidsongeschikt? Of brengt een redelijke uitleg met zich dat hij $100 \%$ beroepsarbeidsongeschikt is?

38. Rb. Gelderland 25 november 2015, ECLI:NL:RBGEL:2015:7395. 
Bij de beantwoording van deze vraag is van belang dat veel polisvoorwaarden een 'taakverschuivingsbepaling' bevatten. Een voorbeeld van een dergelijke bepaling is: ${ }^{39}$

'(...) Bij het vaststellen van de werkzaamheden houden we rekening met mogelijke taakaanpassingen, taakverschuivingen, en/of aanpassing van werkomstandigheden (...).'

In een langlopende procedure bij het Gerechtshof 's-Hertogenbosch, die aanving met een dagvaarding van 14 april $2011^{40}$ en eindigde bij arrest van 28 april $2015,{ }^{41}$ oordeelde het hof na benoeming van de nodige deskundigen dat een hovenier volledig beroepsarbeidsongeschikt was voor zijn verzekerde beroep. Achmea betoogde in deze procedure dat de arbeidsongeschiktheid moest worden beoordeeld per taak, waardoor de verzekerde nog 487,75 uur per week (=22\%) arbeidsgeschikt zou zijn. Het hof volgt echter de door hem benoemde deskundige in zijn oordeel:

'Ik zie voor deze man geen mogelijkheden in het eigen bedrijf. Ook zijn door de zwaarte van de beperkingen geen aanpassingen mogelijk. Hij kan geen machines besturen of bedienen, hij kan nauwelijks voorwerpen hanteren, de grens ligt voor een beperkte periode op $1 \mathrm{~kg}$. Het betreft een beroep met fysieke belasting die bij vrijwel alle handelingen wordt overschreden. Deze betrokkene is voor zijn beroep volledig ongeschikt.'

Achmea betoogde voorts, in het kader van de taakverschuivingsbepaling, dat de verzekerde regelmatig personeel inschakelde, althans met andere zzp'ers samenwerkte, zodat dit ook in de toekomst van hem verwacht mocht worden, hetgeen invloed had op het percentage beroepsarbeidsongeschiktheid. Ook hier gaat het hof niet in mee.

Het hof wijst er enerzijds op dat de verzekerde weliswaar had verklaard dat hij vijf à zes personen per jaar inschakelde, maar dat niet was geconcretiseerd om hoeveel uur het ging, en anderzijds dat waar gesproken werd over 'werken in teamverband' het niet de verzekerde was die mensen inhuurde, maar dat $h i j$ werd ingehuurd door derden. Tegen deze achtergrond komt het oordeel van het hof mij als terecht voor.

In diens vonnis van 26 april 2017 komt de Rechtbank Midden-Nederland ${ }^{42}$ tot een ander oordeel. In die zaak ging het om een zelfstandig glaszetter. $\mathrm{Na}$ specialistisch medisch onderzoek, een verzekeringsgeneeskundig en een arbeidsdeskundig onderzoek concludeert de verzekeraar dat verzekerde voor $72 \%$ arbeidsongeschikt is. Tegen deze vaststelling maakt verzekerde bezwaar. De rechtbank oordeelt echter:

39. Ontleend aan: Hof's-Hertogenbosch 25 april 2017, ECLI:NL:GHSHE: 2017:1843, JA 2017/116 m.nt. E.J. Wervelman.

40. Te kennen uit: Hof's-Hertogenbosch 12 juni 2012, ECLI:NL:GHSHE: 2012:BW8401, het eerste van vier tussenarresten.

41. Hof's-Hertogenbosch 28 april 2015, ECLI:NL:GHSHE:2015:1563.

42. Rb. Midden-Nederland 26 april 2017, ECLI:NL:RBMNE:2017:2047.
'Dit [de door de verzekeraar gehanteerde berekenwijze; EB] is de gebruikelijke manier van rekenen. De functie wordt opgedeeld in deeltaken; voor elk van die deeltaken wordt de uitval berekend; op basis daarvan wordt de uitval voor het totaal berekend. Dit is een theoretische benadering, waarbij alle taken gelijkelijk meetellen. [Eiser] voert terecht aan dat uitval in de ene deeltaak kan doorwerken in de andere. Als men geen uitvoerend werk meer kan doen, kan dat betekenen dat men ook uitvalt voor reistijd en administratie, omdat er niets meer te reizen of te administreren valt. Dat spreekt echter niet vanzelf, omdat men op basis van de polisvoorwaarden ook moet kijken naar de mogelijkheid van aanpassingen in het werk [curs. EB]. [Eiser] heeft bijvoorbeeld gesproken over het uitbreiden van de handel in glas, en hij heeft ook arbeid ingehuurd. Dat kan ertoe leiden dat de uitval voor administratieve taken minder is dan die voor uitvoerend werk. Arbeidsdeskundige [A] heeft op basis van de jaarcijfers ook vastgesteld dat de omzet van [eiser] in 2014 was gedaald met maar 55\%. Dat wijst erop dat hij toen voor een groot deel arbeidsongeschikt was, maar niet dat zijn bedrijf op dat moment feitelijk stil lag.'

Ook het Gerechtshof 's-Hertogenbosch komt in 2017 over eenzelfde vraag te oordelen. In die zaak was de verzekerde eigenaar van een eenmanszaak in het leveren en aanleggen van elektrische vloerverwarming. Zijn werkzaamheden bestonden uit de verkoop en het aanleggen van elektrische vloerverwarmingen en de administratie daarvan. Achmea keerde uit op basis van $70 \%$ arbeidsongeschiktheid, omdat verzekerde de uitvoerende werkzaamheden (het installeerwerk) niet meer kon uitvoeren.

Bij de rechtbank ${ }^{43}$ vond verzekerde gehoor met zijn betoog dat hij daardoor volledig arbeidsongeschikt was, omdat zijn niet-uitvoerende taken niet los konden worden gezien van de uitvoerende werkzaamheden. Het hof gaat daar in appel echter niet in mee. $\mathrm{Na}$ een uitvoerige beschouwing overweegt het hof onder meer:

'Al het vorenstaande in ogenschouw nemend, is het hof van oordeel dat met het woord "arbeidsongeschiktheid" niet is bedoeld dat [geïntimeerde] al een volledige uitkering ontvangt indien hij alleen arbeidsongeschikt is om vloerverwarming aan te leggen. Van belang is ook welke werkzaamheden [geïntimeerde] nog kan uitoefenen binnen het door hem opgegeven hoofdberoep en met inachtneming van hetgeen het polisblad vermeldt omtrent het verzekerde beroep. Vaststaat dat hij nog $30 \%$ van zijn volledige arbeidstijd aan werkzaamheden binnen zijn hoofdberoep kan uitoefenen, hetgeen een substantieel deel van de beschikbare arbeidstijd is.'

43. Rb. Oost-Brabant 29 oktober 2014, ECLI:NL-RBOBR:2014:6520. 
Het hof vernietigt vervolgens het vonnis van de rechtbank en wijst - opnieuw rechtdoende - de vorderingen van de verzekeringnemer af. In zijn noot onder dit arrest in de $\mathrm{JA}^{44}$ merkt Wervelman op dat het oordeel van de rechtbank de takkerschuivingsbepaling bij eenmanszaken tot een dode letter zou maken, temeer omdat in het berechte geval bekend was dat de verzekerde incidenteel derden inschakelde, en schaart zich achter het oordeel van het hof.

Mijns inziens ligt een en ander genuanceerder. Wanneer de verzekerde inderdaad een zzp'er is (het feit dat het een eenmanszaak is zegt niets over het al dan niet in dienst hebben van personeel, maar slechts iets over de rechtsvorm), en hij arbeidsongeschikt is voor de feitelijke werkzaamheden, waardoor alleen het voeren van administratie en het bijhouden van de vakliteratuur overblijven, dan komt mij de insteek van de rechtbank in beginsel juist voor. Ik meen dat niet te snel van een zzp'er mag worden verwacht dat hij van een zelfstandige die de werkzaamheden in principe zelf verricht (het enkele feit dat hij voor de uitvoering van aangenomen werk af en toe een derde inschakelt doet niet aan dit uitgangspunt af), transformeert in een soort zakenman die het werk wel binnenhaalt maar niet meer zelf uitvoert. Dat is niet alleen een heel andere 'tak van sport', maar in het kader van de arbeidsongeschiktheidsverzekering ook een geheel andere functie. Dat de taakverschuivingsbepaling bij een zzp'er in dat soort gevallen een dode letter is, is iets dat de verzekeraar bekend is c.q. kan zijn bij het aangaan van de verzekering. Wanneer echter de resterende arbeidscapaciteit kan worden aangewend om binnen het hoofdberoep inkomen te verwerven (desnoods door een accentverschuiving), dan komt mij het oordeel van het hof juist voor.

\section{Acceptatiebeleid = maatschappijbeleid?}

Een laatste ontwikkeling die ik behandel in het kader van deze bijdrage is het acceptatiebeleid van verzekeraars bij de arbeidsongeschiktheidsverzekering. Dit doe ik omdat in relatief korte tijd twee verschillende hoven arrest hebben gewezen over eenzelfde onderwerp, maar tot een diametraal andere uitkomst komen.

In beide gevallen ging het om de schending van de mededelingsplicht bij het aangaan van de verzekering. Doorgaans wordt een aanvraagformulier gebruikt, waarin de verzekeraar vragen stelt over onder meer de gezondheidstoestand van de kandidaat-verzekerde. Op basis van de daarop gegeven antwoorden kan de verzekeraar inschatten welk risico hij na acceptatie loopt en of hij, en zo ja onder welke voorwaarden, bereid is dit risico te lopen.

In de jurisprudentie rond de mededelingsplicht bij het aangaan van de verzekering ${ }^{45}$ komt op enig moment, als vastgesteld is dat de kandidaat-verzekeringnemer zijn mededelings-

44. Hof 's-Hertogenbosch 25 april 2017, ECLI:NL:GHSHE:2017:1843, JA 2017/116 m.nt. E.J. Wervelman.

45. Art. 7:928 BW. plicht verzaakt heeft, de vraag naar voren wat de verzekeraar zou hebben gedaan indien hij bij het aangaan van de verzekering bekend zou zijn geweest met de ware stand van zaken. Had hij de verzekering op dezelfde voorwaarden en tegen dezelfde premie gesloten, dan heeft de schending van de mededelingsplicht geen gevolgen. ${ }^{46}$ Zou de verzekeraar een hogere premie hebben bedongen of tegen een lager bedrag hebben verzekerd, dan wordt de uitkering naar rato verminderd. ${ }^{47}$ Had de verzekeraar andere voorwaarden gesteld, dan is slechts een uitkering verschuldigd als dat op basis van die voorwaarden het geval is. ${ }^{48}$ Alleen wanneer er sprake was van de opzet om te misleiden ${ }^{49}$ of wanneer de verzekeraar de polis bij kennis van de ware stand van zaken niet zou hebben gesloten, ${ }^{50}$ is de verzekeraar in het geheel niet tot enige uitkering verplicht.

Aangezien deze discussie doorgaans ontstaat nadat de verzekerde zich arbeidsongeschikt heeft gemeld, kan een verzekeraar er belang bij hebben om te stellen dat hij, bij kennis van de ware stand van zaken, geen verzekering zou hebben gesloten. De verzekeraar hoeft dan immers niet uit te keren. Wordt dit door de verzekeringnemer gemotiveerd betwist, dan zal de rechter moeten vaststellen wat de verzekeraar gedaan zou hebben indien hij tijdig bekend was geweest met de ware stand van zaken. Maar hoe stelt de rechter dit vast?

\section{Het Gerechtshof Amsterdam oordeelde op 4 april 2017: ${ }^{51}$}

'(...) Anders dan de rechtbank heeft overwogen, volgt uit de wetsgeschiedenis bij deze artikelen niet dat bij de toepassing van dit criterium slechts bepalend is of "een redelijk handelend verzekeraar" bij kennis van de ware stand van zaken een verzekering zou hebben gesloten en niet wat de verzekeraar aan de hand van zijn individuele acceptatiebeleid had gedaan. (...) Naar het oordeel van het hof heeft Delta Lloyd haar acceptatiebeleid derhalve voldoende aangetoond. (...) Gelet op een en ander, heeft [appellant] de stelling van Delta Lloyd dat zij bij kennis van de ware stand van zaken geen verzekering zou hebben gesloten, onvoldoende gemotiveerd betwist. (...)'

Terwijl het Gerechtshof 's-Hertogenbosch op 4 juli $2017^{52}$ overwoog:

'Het komt het hof geraden voor om ter zake een deskundige de vraag te laten beantwoorden of een redelijk handelend verzekeraar, indien hij in september 2009 een aanvraag als de onderhavige van [appellant] zou hebben ontvangen, die zou zijn ingevuld conform productie 6 bij inleidend verzoekschrift en de antwoorden zoals vermeld in de bij akte d.d. 4 oktober 2016 door [appellant] overge-
46. Art. 7:930 lid 2 BW.
47. Art. 7:930 lid $3 \mathrm{BW}$.
48. Art. 7:930 lid 3 BW.
49. Art. 7:930 lid 5 BW.
50. Art. 7:930 lid 4 BW.
51. Hof Amsterdam 4 april 2017, ECLI:NL:GHAMS:2017:1195.
52. Hof's-Hertogenbosch 4 juli 2017, ECLI:NL:GHSHE:2017:3038. 


\section{Maandblad}

legde productie, de aanvraag zonder meer zou hebben afgewezen, dan wel nader onderzoek zou hebben gedaan en, indien nader onderzoek zou zijn gedaan, waaruit dit nader onderzoek dan zou hebben bestaan.'

Hoewel deze discussie ogenschijnlijk minder imponeert dan de hiervoor weergegeven discussies, kan ook hier het belang niet snel worden onderschat. Deze discussie rakt immers aan de partijautonomie: of, en zo ja onder welke voorwaarden, een verzekeraar het individuele risico op arbeidsongeschiktheid wil verzekeren. Indien geoordeeld zou worden dat moet worden gekeken naar hetgeen een redelijk handelend verzekeraar zou doen, komt minder betekenis toe aan de eigen beleidskeuzes van de betreffende verzekeraar dan wanneer het eigen acceptatiebeleid doorslaggevend zou zijn.

In de Amsterdamse zaak werd tijdig cassatie ingesteld. In cassatie is - onder meer - geklaagd dat het hof is uitgegaan van een onjuiste rechtsopvatting door het handelen van Delta Lloyd niet (primair) te toetsen aan dat van de 'redelijk handelend verzekeraar'.

Op 15 juni 2018 is door A-G Wissink geconcludeerd. ${ }^{53}$ Wissink makt in zijn conclusie een scheiding tussen de situatie onder het oude recht (tot 2006) en de situatie daarna. Hij wijst onder meer op de beantwoording door de minister in de Eerste Kamer, die op dit punt antwoordde: ${ }^{54}$

'Het arrest Hotel Wilhelmina is niet met zoveel woorden in het nieuwe recht neergelegd. In art. 7:928 lid 1 wordt immers gesproken over feiten waarvan de beslissing van de verzekeraar afhangt of kan afhangen.

Indien evenwel een verzekeraar een acceptatiebeleid hanteert dat afwijkt van dat van een redelijk handelende verzekeraar, dan is dit bij toepassing van artikel 7.17.1.4 lid 1 [art. 7:928 lid 1 BW; A-G] alleen van betekenis indien de verzekeringnemer zulks wist of behoorde te begrijpen. Is dit laatste niet het geval dan zal ingevolge 7.17.1.4 lid 1 [art. 7:928 lid 1 BW; A-G] buiten de mededelingsplicht vallen hetgeen een verzekeraar, anders dan andere verzekeraars, relevant acht. Langs deze weg wordt een zelfde resultaat bereikt als met het door deze leden genoemde arrest. Zie ook Asser/Clausing-Wansink, 5-VI, nr. 104. Wordt aldus een beperking bereikt voor de omvang van de mededelingsplicht, dan werkt dit ook door in art. 7.17.1.6 lid 4 [art. 7:930 lid 4 BW; A-G], in die zin dat de verzekeraar voor aldus buiten de mededelingsplicht vallende feiten zich ook niet aan uitkering kan onttrekken door te stellen dat hij bij kennis daarvan in het geheel geen verzekering zou hebben gesloten.'
Wissink concludeert op dit punt dan ook:

'Ik kom tot de slotsom dat ook naar huidig recht de hypothetische acceptatiebeslissing dient te worden gebaseerd op het acceptatiebeleid van de maatman-verzekeraar ("de redelijk handelende verzekeraar”), of op het (daarvan afwijkende) acceptatiebeleid van de individuele verzekeraar indien dat aan de verzekeringnemer kenbaar is gemaakt.'

Tegen die achtergrond wekt het geen verbazing dat Wissink van oordeel is dat het hof is uitgegaan van een onjuiste rechtsopvatting en alsmede de Hoge Raad adviseert om het arrest te casseren.

Ook in deze discussie is de Hoge Raad nu aan zet. Volgt de Raad het advies van de A-G die, op het spoor van de heersende leer in de literatuur, ${ }^{55}$ concludeert tot cassatie, of komt de Raad tot een ander oordeel? De tijd zal het ons leren.

\section{Tot slot}

Het voorgaande toont aan dat het recht rond de private arbeidsongeschiktheidsverzekering volop in beweging is. Van een rustig bezit is allerminst sprake.

Zoals in de inleiding al is aangestipt, wordt het maatschappelijk belang van de private arbeidsongeschiktheidsverzekering door het groeiend aantal zelfstandigen, al dan niet zonder personeel, steeds groter. Dat gevoegd bij het financielle belang van partijen bij een beroep op de arbeidsongeschiktheidsverzekering doet mij vermoeden dat het laatste woord hierover nog lang niet gezegd is.

Binnen afzienbare tijd is in ieder geval op twee fronten een nadere duiding door de Hoge Raad te verwachten: (1) 'Wie wijst de deskundige aan?' en (2) 'Welke maatstaf moet er worden aangelegd na schending van de mededelingsplicht?' Wat de Raad ook beslist: ik verwacht dat dit de nodige pennen in beweging zal zetten.
53. De conclusie is op 5 juli 2018 op rechtspraak.nl gepubliceerd: ECLI:NL:PHR:2018:689.

54. Parl. Gesch. Boek 7, titel 17 BW, p. 27 (Verslag I Invoering 7.17).
55. Zie onder meer: K. Engel, De precontractuele mededelingsplicht van de verzekeringnemer in rechtsvergelijkend perspectief, Zutphen: Paris 2016. 